\section{Postharvest Irrigation Influences Budbreak of 'Perlette' Grapevines}

Larry E. Williams ${ }^{1}$

Kearney Ag Center, 9240 South Riverbend Avenue, Parlier, CA 93648

Rudy A. Neja ${ }^{2}$

University of California, Cooperative Extension, 83612 Avenue 45, Suite

7, Indio, CA 92201

Jewell L. Meyer ${ }^{3}$

Department of Soils and Environmental Sciences, University of

California, Riverside, CA 92521

Lori A. Yates ${ }^{4}$

Department of Statistics, University of California, Riverside, CA 92521

Eddie L. Walker ${ }^{5}$

Karahadian Ranches, Inc., P.O. Box 756, Thermal, CA 92274

Additional index words. Vitis vinifera, table grapes, desert, irrigation timing, irrigation quantity

Vine growth and development in the Coachella Valley of southern California (a desert climate) begins in early February and grape (Vitis vinifera L.) harvest is completed sometime in June. Growers generally irrigate vines after harvest to the extent that vegetative growth becomes excessive in many vineyards. However, subdued light, such as that found in the interior of a dense canopy, will result in low bud fruitfulness (May, 1965). Vegetative growth during this time could be controlled through irrigation management. If a reduction in the amount of applied water would reduce vegetative growth without affecting vine productivity the following year, substantial savings in both water and pumping costs could be realized. Therefore, a study was initiated in 1987 to investigate the effects of postharvest irrigation regimes on budbreak of 'Perlette' grapevines grown in the Coachella Valley.

The experiment was initiated in a vineyard $8 \mathrm{~km}$ east of Thermal, Calif., on 1 July 1987 and repeated in 1988. Vines were trained to a bilateral cordon. The experiment was designed as a split plot, with two irrigation cutoff dates being the main plots and four irrigation rates being the subplots. The subplots contained nine vines for data collection, with two guard rows and two guard vines sepa-

Received for publication 29 June 1990. The cost of publishing this paper was defrayed in part by the payment of page charges. Under postal regulations, this paper therefore must be hereby marked advertisement solely to indicate this fact.

'Associate Professor, Univ. of California, Davis. ${ }^{2}$ Farm Advisor, Riverside County.

${ }^{3}$ Extension Specialist.

${ }^{4}$ Extension Statistician.

${ }^{5}$ Vineyard Manager. Valley of California. both cut-off dates. a given year. rating all subplots. The water cut-off dates were 15 Sept. and 1 Dec. The standard irrigation treatment was based on a combination of reference crop evapotranspiration (ET) (obtained from the California Irrigation and Management Information System's weather station near Thermal, Calif.), historical water needs, a crop coefficient $\left(\mathrm{k}_{\mathrm{c}}\right)$ of 0.6 , and soil moisture content. An additional three irrigation treatments were various fractions of the standard postharvest irrigation treatment. These treatments were obtained using a combination of 3.7- and 7.4-liters. $\mathrm{h}^{-1}$ emitters.

Budbreak was determined by counting all buds retained after pruning and then recording the appearance of green shoot tissue as the shoot developed. Two vines per subplot were used to determine budbreak. Data were tested by analysis of variance. Treatment means for the irrigation rates were separated using Fisher's protected LSD method at the $P=0.05$ level.

The amount of water applied to the standard treatment (late cut off) was $\approx 350 \mathrm{~mm}$ both years. The amount of water applied to vines in the standard treatment (early cut off) in 1987 was $234 \mathrm{~mm}$, and in 1988, it was $250 \mathrm{~mm}$. The amounts of water applied to the additional irrigation rate treatments were $150 \%, 87.5 \%$, and $62.5 \%$ of that applied to the standard treatments. ET, from 1 July until 1 Dec. was $\approx 641 \mathrm{~mm}$ in both years.

Shortly after the early irrigation cut-off date, leaves abscised both years for most of the irrigation rates in those treatments. Budbreak was significantly earlier for vines with the early cut off of water both years than for those with the late cut off of irrigation (Table 1). As vines received less postharvest irrigation water in 1988, their buds broke earlier in 1989. A similar pattern was observed in 1988; however, then there were no significant differences among treatments (data not shown)

Fruit from this region is the first to market and generally sets the pattern for consumer purchases throughout the remainder of the season. Therefore, the earlier a grower can harvest high-quality fruit, the more the crop is worth. The data indicate that postharvest irrigation cut-off date and amount are important in controlling the date of budbreak for 'Perlette' grapevines the next growing season.

\section{Literature Cited}

May, P. 1965. Reducing inflorescence formation by shading individual Sultana buds. Austral. J. Biol. Sci. 18:463-473.

Table 1. Effect of postharvest irrigation cut-off dates in 1987 and 1988 and various irrigation levels in 1988 on budbreak the following growing seasons for 'Perlette' grapevines grown in the Coachella

\begin{tabular}{|c|c|c|c|c|c|c|}
\hline \multirow{2}{*}{$\begin{array}{c}\text { Year of } \\
\text { observation }\end{array}$} & \multirow[b]{2}{*}{ Treatment } & \multicolumn{5}{|c|}{ Calendar date } \\
\hline & & $10 \mathrm{Feb}$. & $16 \mathrm{Feb}$. & $23 \mathrm{Feb}$. & 1 Mar. $^{2}$ & $15 \mathrm{Mar}$ \\
\hline & & \multicolumn{5}{|c|}{ No. buds that broke/viney } \\
\hline & Cut-off date & & & & & \\
\hline \multirow[t]{2}{*}{1988} & Early & $8 * *$ & $43^{* * *}$ & 70 & 78 & --- \\
\hline & Late & 4 & 27 & 63 & 77 & .... \\
\hline \multirow[t]{3}{*}{1989} & Early & 11 & $29^{*}$ & $67^{* *}$ & $93^{*}$ & 106 \\
\hline & Late & 7 & 21 & 58 & 88 & 101 \\
\hline & Irrigation level'x & & & & & \\
\hline \multirow[t]{5}{*}{1989} & $+50 \%$ & 7 & 21 & 52 & 80 & 93 \\
\hline & Standard & 9 & 24 & 61 & 90 & 104 \\
\hline & $-12.5 \%$ & 10 & 28 & 69 & 98 & 112 \\
\hline & $-37.5 \%$ & 11 & 29 & 69 & 94 & 106 \\
\hline & $L^{L S D_{0.05}}$ & NS & 3 & 7 & 8 & 8 \\
\hline
\end{tabular}

z1 Mar. was the last date for which budbreak data were collected in 1988 .

YThese values were obtained by counting the appearance of new shoots that had developed from dormant buds on count spurs and the growth of shoots from the basal whorl of buds from the spur.

${ }^{x}$ There were no interactions between cut-off dates and irrigation levels. Values represent the means of

$*, * *, * * *$ Significant differences at $P=0.05,0.01$, and 0.001 , respectively, between cut-off dates within 